Received: 19 June 2020

Accepted: 10 August 2020

Online: 12 August 2020

Authors:

Bhaswati Lahiri $₫$, Rekha Rani

Department of Dairy Technology,

Warner College of Dairy Technology,

Sam Higginbottom University of Agriculture,

Technology and Sciences, Prayagraj, India

$\bigotimes$ bhaswati281121@gmail.com

Emer Life Sci Res (2020) 6(2): 1-4

E-ISSN: 2395-6658

P-ISSN: 2395-664X

DOI: https://doi.org/10.31783/elsr.2020.620104

\section{Review Article \\ Garden Cress Seeds: chemistry, medicinal properties, application in dairy and food industry: A Review}

\author{
Bhaswati Lahiri, Rekha Rani
}

\begin{abstract}
Lepidium sativum also known as Garden Cress seeds contains several medicinal properties such as antioxidant properties, anti-anemic properties, anti-diabetic properties, anti-inflammatory properties, hepatoprotective properties, antimicrobial properties and chemoprotective properties. It can also be used to develop functional foods by fortification. Since the ancient period Garden Cress seeds have been used for medicinal purposes. It also has application in several diseases like asthma, diarrhea, in many skin diseases such as scurvy, etc. It is also useful for increasing the milk secretions in lactating mothers. Garden Cress seeds contain a remarkable amount of calcium, iron, folic acid, Vitamin A, and Vitamin C. Their higher protein and lipid contents indicate that the seeds serve high energy. Its methionine is beneficial in the digestion process as well as plays an important role in the burning of fat and lysine is important in the nitrogen balance. Garden Cress seeds are used in the fortification of food and dairy products like Dahiwala bread, omega-3-fatty acid-rich biscuits, iron-rich biscuits, health drinks, vegetable oils blended with alpha-linoleic acid-rich Garden Cress oil, fortified burfi, fortified chikki etc.
\end{abstract}

Keywords antioxidant, anti-anemic, anti-inflammatory, food application, garden cress seeds

\section{Introduction}

Lepidium sativum also known as Garden Cress seeds or in local language known as "Chandrasur" belongs to the family Brassicaceae (Cruciferae). Lepidium sativum's main feature is that it can be grown in any type of climate and soil condition, and has an ability to tolerate slight acidity in soil and can be grown like white mustard [1]. It contains several medicinal properties like antioxidant properties, anti-anaemic properties, anti-diabetic properties, antiinflammatory properties, hepato-protective properties, antimicrobial properties and chemo- protective properties. It can also be used to develop functional food by fortification [2]. Garden Cress seeds increase the protein and fat content in fruit and vegetable juices. Since the ancient period, Garden Cress seeds have been used for medicinal purposes. It has application in several diseases like asthma, diarrhea and many skin diseases such as scurvy, etc. It is also useful for increasing the milk secretions in lactating mother. Garden Cress seed oil is highly beneficial because its polyunsaturated fatty acids (PUFA) value is $46.8 \%$ and monounsaturated fatty acids (MUFA) value is $37.6 \%$. It contains vitamin $A$ and vitamin $E$ which helps in the protection of cells from the damage and Garden Cress seeds oil protects from oxidation and rancidity. 


\section{Chemical composition and utilization}

Garden Cress seeds contain a remarkable amount of calcium, iron, folic acid, vitamin A and Vitamin C. Glucosinolate is the major secondary compound of Garden Cress seeds. The percent nutrient composition of L. sativum contains $24.2 \%$ protein i.e., $30.7 \%$ carbohydrates, $11.9 \%$ fiber, $7.1 \%$ ash, and $2.9 \%$ moisture. Higher protein and lipid contents indicate that the seeds serve high energy [3]. The total essential amino acid content such as histidine, threonine, arginine, valine, methionine, phenylalanine, and isoleucine is $47.08 \%$. Methionine is beneficial in the digestion process as well as plays an important role in the burning of fat. Lysine is important in the nitrogen balance. Garden Cress seeds also contain a significant amount of minerals. Garden Cress seeds contain $3.87 \mathrm{gm}$ histidine, $2.66 \mathrm{gm}$ threonine, $4.51 \mathrm{gm}$ arginine $3.04 \mathrm{gm}$ valine, $0.97 \mathrm{gm}$ methionine, $5.67 \mathrm{gm}$ phenylalanine, $5.11 \mathrm{gm}$ isoleucine and $6.26 \mathrm{gm}$ lysine respectively. It also contains $9.76 \mathrm{gm}$ aspartic acid, $19.33 \mathrm{gm}$ glutamic acid, $4.96 \mathrm{gm}$ serine, $5.51 \mathrm{gm}$ glycine, $4.83 \mathrm{gm}$ alanine, $2.69 \mathrm{gm}$ tyrosine, $5.84 \mathrm{gm}$ proline, $266.35 \mathrm{mg}$ calcium, $5.73 \mathrm{mg}$ copper, $8.31 \mathrm{mg}$ iron, $339.23 \mathrm{mg}$ magnesium, $2.00 \mathrm{mg}$ manganese, $608.63 \mathrm{mg}$ phosphorus, $1236.51 \mathrm{mg}$ potassium, $19.65 \mathrm{mg}$ sodium, and $6.99 \mathrm{mg}$ zinc respectively [4].

\section{Pharmacological activity of Lepidium sativum}

\section{Anti-inflammatory effect of Lepidium sativum}

The Garden Cress plant contains imidazole, essential, and non-essential amino acids. Garden Cress seeds have medicinal properties like anti-inflammatory properties [5]. The presence of flavonoids, alkaloids, cyanogenic glycosides (traces), tannins, glucosinolates, sterols, and triterpenes in Garden Cress seeds contribute to this effect [6]. A study had been done on rodents to study the anti-inflammatory effects and the results showed that an ethanolic extract of Garden Cress seeds inhibit the carrageenan-induced paw edema and reduced the hyperpyrexia effect [7].

\section{Hepatoprotective effect of Lepidium sativum}

Garden Cress seeds are rich in iron and have hepatoprotective effects [8]. A pretreatment of Lepidium sativum ethanolic extract (LSEE) given to the liver damaged rats showed that LSEE downregulated the caspase 3 and up-regulated the $\mathrm{BCl}_{2}$ protein expression [9]. Another study organized to determine the hepatoprotective effect of Garden Cress seeds was conducted using its chloroform extract that was given to the liver damaged rats and the results showed that it inhibited the reactive oxygen species (ROS) generation and increased the mitochondrial membrane potential [10].

\section{Antioxidant property of Lepidium sativum}

This property depends on the phenolic compounds present in Garden Cress seeds such as tocopherols that act as a scavenger of free radicals and prevent many diseases [11]. Ethanolic extract of garden cress seeds have antioxidant properties and it also acts as a free radical scavenger [12]. Antioxidant properties in food product increase the food product's shelf life and decrease the nutritional losses and also decrease the raw material waste [13].

\section{Anti-diabetic effect of Lepidium sativum}

Garden Cress seeds have alkaloids that are beneficial against diabetes [14]. An aqueous extract of Lepidium sativum has been proved as an antidiabetic and it has a hypoglycemic effect independent of insulin secretion. Garden Cress seeds are used for the treatment of diabetes mellitus [15].

\section{Fortification of food products using Garden Cress seeds}

Many drinks and foods are fortified with Garden Cress seeds to increase the nutritional and functional properties. Some of the Garden Cress seeds fortified products are discussed below: 


\section{Dahiwala bread}

It is a breakfast item that is very easy to cook and prepared by mixing the curd along with bread slice. After mixing, the slice of bread is fried where soybean oil is used to avoid saturated fat. It is fortified with Garden Cress Seeds. This product is developed with an increased amount of protein, fat, calcium, iron, and phosphorous. This product could be beneficial for nourishment and act as a therapeutic agent due to the presence of many therapeutic properties [16].

\section{Omega-3-fatty acid-rich biscuits}

These are prepared by adding microencapsulated Garden Cress seed oil at a concentration of $20 \mathrm{~g} / 100 \mathrm{~g}$ with alanine (Ala) content of $1.02 \mathrm{~g} / 100 \mathrm{~g}$. $1.05 \mathrm{~g} / 100 \mathrm{~g}$ metalized PET film was used for packaging the biscuits [17].

\section{Health drinks}

As Garden Cress seeds are rich in proteins, carbohydrates, and certain essential minerals like calcium, iron, and phosphorous along with crude dietary fiber (7.6\%), it can be used to prepare the health drinks with milk. The composition of milk-based health drink is $5 \%$ sugar (w/v), $1 \%$ fat, and $3 \%$ of processed Garden Cress seeds [4]. It mainly fulfills the need of growing children, the aged, infants and also certain convalescent patients. It enhances the nutritional properties of milk and also provides all the essential factors that are needed by these people. This type of drink aids to avert nutrient deficiency and endorses lean muscle developments in persons doing regular exercise.

\section{Vegetable oil blends with $\alpha$-linolenic acid-rich garden cress oil}

The eating of vegetable oils (sunflower, corn oil, safflower oil, and soybean oil) rich in n-6 PUFA has shifted the n-6 to n-3PUFA ratio to 50:1 instead of a recommended ratio of 10:1 or 2:1. Umesha and Naidu [18] developed a blended vegetable oil and studied its modulatory effects on lipid metabolism by mixing the vegetable oil and Garden Cress seed oil. In their experiment, different ratios of Garden Cress seed oil was mixed with the rice bran oil, sunflower oil, and sesame oil to develop the vegetable oils with PUFA ratio of 2.3-2.6 and to study their modulatory effect on lipid metabolism [18-19].

\section{Fortified burfi}

Burfi prepared by Bengal gram flour is roasted with ghee in a slow flame and the sugar syrup is added in it and also 15 percent Garden Cress seeds are added then the mixture is spread and after settling, cut in to square shapes with knife. It is proved to be highly nutritious and delicious [20].

\section{Fortified chikki}

Jaggery is crushed and mixed with water to prepare a syrup by heating it at $145^{\circ} \mathrm{C}$ and roasted peanuts and Garden Cress seeds powder are also added to them after turning off the flame. Further, the mixture was poured on a greased surface and after settling, cut into square pieces and allowed for cooling. Chikki fortified with Garden Cress seeds is brownish in color due to the dark brown color of the seeds where crunchiness of the seeds improves the texture of the chikki [20].

\section{Conclusion}

As Garden Cress seeds contain antioxidant properties, it is observed that the garden cress plants are a good source of amino acids, minerals, fatty acids. It can be used to prepare many of functional and nutritional fortified food products. It helps in the prevention of several diseases and increasing the hemoglobin level of patients. It has many medicinal properties such as anti-inflammatory properties, anti-diabetic properties, hepatoprotective properties, anti-microbial properties and chemoprotective properties. Thus, it can be concluded that the ready to eat Indian supplementary food can be successfully fortified by using Garden Cress seeds which have high nutritional value and may serve as a boon for our malnourished population.

\section{References}


[1] S. Sharma and N. Agarwal (2011). Nourishing and healing process of garden cress (Lepidium sativum Linn). Indian J. Natural Prod. Resour., 2: 292-297.

[2] P. N. Tiwari and G. S. Kulmi (2004). Performance of Chandrasur (Lepidium sativum) under different levels of nitrogen and phosphorus. J. Med. Arom. Pl. Sci., 26: 479-481.

[3] S. S. Gokavi, N. G. Malleshi and M. Guo (2004). Chemical composition of garden cress (Lepidium sativum) seeds and its fractions and use of bran as a functional ingredient. Plant Foods Hum. Nutr. 59:105-111.

[4] C. S. Singh and V. H. Pashwan (2017). The Potential of Garden Cress (Lepidium sativum L.) seeds for development of functional foods, Advances in Seed Biology, Jose C. Jimenez-Lopez, IntechOpen, doi: 10.5772/intechopen.70355.

[5] N. U. Rehman, A. U. Khan, K. M. Alkharfy and A. H. Gilani (2012). Pharmacological Basis for the Medicinal Use of Lepidiumsativum in Airways Disorders. Evid. Based Complementary Alternat Med., doi:10.1155/2012/596524.

[6] S. Wadhwa, M. S. Panwar, A. A. grawal, N. Saini, L. N. Patidar (2012). A review on pharmacognostical study of Lepidium sativum. Adv. Res. Pharmaceuticals Biologicals, 2: 316-323.

[7] N. D .Raval, B. Ravishankar and B. K. Ashok (2013). Anti-inflammatory effect of chandrashura (Lepidium sativum Linn.) an experimental study. AYU, 34: 302-304.

[8] Shail, M. Dwivedi, N. Kumar and L. N. Gupta (2016). Nutritional importance of Lepidium sativum L. (Garden cress/Chandrashoor). Int. J. Pharm. Anal. Res., 5: 152-160.

[9] M. Raish, A. Ahmad, K. M. Alkharfy, S. R. Ahamad, K. Mohsin, F. I. Jenoobi and A. M. Mohizea (2016). Hepatoprotective activity of Lepidium sativum seeds against Dgalactosamine/lipopolysaccharide induced hepatotoxicity in animal model. BMC Complement. Altern. Med., 16: 501. doi: 10.1186/s12906-016-1483-4.

[10] E. S. Al-Sheddi, N. N. Farshori, M. M. Al-Oqail, J. Musarrat, A. A. Al-Khedhairy and M. Siddhiqui (2016). Protective effect of Lepidium sativum seed extract against hydrogen peroxide-induced cytotoxicity and oxidative stress in human liver cells (HepG2). Pharm. Biol., 54: 314-321.

[11] R. B.-Flohe, F. J. Kelly, J. T. Salonem, J. Neuzil, J.-M. Zingg and A. Azzi (2002). The European perspective on vitamin E: Current knowledge and future research. Am. J. Clin. Nutr., 76: 703-716.

[12] J. Malar, K. Chairman, A. R. J. Singh, J. S. Vanmathiand, K. Vasanthi (2014). Antioxidative activity of different parts of the plant Lepidiumsativum Linn. Biotechnol. Rep., 3: 95-98.

[13] M. F. A. El-Maati, S. M. Labib, A. M. A. Al-Gaby and M. F. Ramadan (2016). Antioxidant and antibacterial properties of different extracts of garden cress (Lepidiumsativum L.). Zagazig J. Agric. Res., 43: 1685-1697.

[14] M. R. Prajapati and P. H. Dave (2018). Therapeutic and nutritional importance of garden cress seed. J. Pharmacogn. Phytochem., 7: 140-143.

[15] M. Eddouks, M. Maghrani, A. Lemhadri M.-L. Ouahidi and H. Jouad (2002). Ethnopharmacological survey of medicinal plants used for the treatment of diabetes mellitus, hypertension and cardiac diseases in the South-East region of Morocco (Tafilalet). J. Ethnopharmacol., 82: 97-103.

[16] N. Agarwal and S. Sharma (2013). Appraisal of garden cress (Lepidium sativum L.) and product development as an all pervasive and nutrition worthy food stuff. Annals Food Sci. Technol., 14: 77-84.

[17] S. S. Umesha, R. S. Manohar, A. R. Indiramma, S .Akshitha and K. A. Naidu (2015). Enrichment of biscuits with microencapsulated omega-3 fatty acid (alpha-linolenic acid) rich gardencress (Lepidium sativum) seed oil: Physical, sensory and storage quality characteristics of biscuits. LWT-Food Sci. Technol., 60: 654-661.

[18] S. S. Umesha, K. A. Naidu (2012).Vegetable oil blends with $\alpha$-linolenic acid rich garden cress oil Modulate lipid metabolism in experimental rats. Food Chem., 135: 2845-2851.

[19] S. Gerd and E. Josef (2008). The opposing effects of n-3 and n-6 fatty acids. Prog. Lipid Res., 47: 147155.

[20] T. Jain, K. Grover and I. S. Grewal (2016). Development and sensory evaluation of ready to eat supplementary food using gardencress (Lepidium sativum) seeds. J. Appl. Nat. Sci., 8: 1501-1506. 